\title{
ESTABLISHING THE RATIO OF CONCEPTS OF COUNTERACTION TO LEGALIZATION (LAUNDERING) OF ILLEGALLY-OBTAINED INCOME AND COUNTERACTION TO THE SHADOW ECONOMY: THE IMPORTANCE FOR DETERMINING PERFORMANCE INDICATORS OF THE EUROPEAN INTEGRATION PROCESSES
}

\author{
Olha Tylchyk ${ }^{1}$, Olena Dragan², Olena Nazymko³
}

\begin{abstract}
The vast majority of reports from governments of the European Union member states and applicants for such membership contain a separate provision on ensuring their effectiveness in the system of combating money laundering and terrorist financing, adherence to the requirements of leading international groups and organizations for such measures. In particular, the assessment of compliance with the 40 Recommendations of the Financial Action Task Force (FATF) on combating money laundering and counteraction to terrorist financing, conducted in Ukraine in 2017 and ended with the relevant report of the Committee of Experts of the Council of Europe MONEYVAL (Report, 2018), is systematically evaluated. The mentioned monitoring body of the Council of Europe assesses, in particular, compliance with the main international standards of organizational, technical, and legal provision of counteraction actors in the respective country, making emphasis on the fact that corruption and illegal (shadow) economic activity (and, according to a well-founded author's approach - "shadowing of the economy" - Tylchyk, 2017) are the main threats (risks) of money laundering (Report, 2018). Today it is possible to state the awareness of the need to introduce generally accepted standards into the practice of special subjects of providing economic security, although in the absence of a single vision of their place in the overall system of subjects of national security. At the same time, there is a significant complication regarding the gradual, system, and systematic nature of this activity, which is determined by the aggravation of social tension in society, external aggression, features of the formation of domestic doctrine and legislation traditionally oriented towards the application of the maximally defined concepts, at the same time, to date contain ambiguous provisions as to the content, in particular, the concept of illegally-obtained income, which does not coincide with that specified in the mentioned Standards and other international documents. The above stipulates the urgency to search for optimal ways to eliminate these inconsistencies, which lead to real hampering activities related to providing a counteraction to the legalization (laundering) of illegally-obtained income, in order to secure not only the national interests of Ukraine but also of the entire world. Methodology. The solution of the set purpose is realized using the cognitive potential of the system of philosophical, general scientific, and special methods. Analysis and synthesis allowed identifying the signs of illegally-obtained income, shadow economy, fight against the shadowing of the economy, and forming the latter concept. Methods of grammatical review and interpretation of legal rules helped to identify gaps and other shortcomings of legislation on problems of providing counteraction to the legalization (laundering) of illegally-obtained income, to develop proposals for its improvement, in particular regarding the features of defining the meaning of the concept of "illegally-obtained income" in domestic law field, the correlation of this concept and other economic and legal concepts. The comparative legal method allowed determining the development directions for domestic statutory acts in order to bring them in line with the generally accepted European standards. Practical implications. The level of shadowing of the Ukrainian economy, as well as many other countries of the world, requires the introduction of effective, timely, and consistent measures, in particular, to ensure control over the mentioned processes and create conditions for minimizing the possibilities of legalization
\end{abstract}

\footnotetext{
Corresponding author:

${ }^{1}$ University of the State Fiscal Service of Ukraine, Ukraine.

E-mail: o.v.tilchik@ukr.net

${ }^{2}$ Department of Prosecution and Representation of Citizens and State in Courts, Ukraine.

E-mail: dragan ov@ukr.net

${ }^{3}$ Donetsk Law Institute of MIA of Ukraine, Ukraine.

E-mail: nazymkoov@ukr.net
} 
(laundering) of illegally-obtained income by the efforts of the system of subjects of providing national (including economic) security to counteract the shadowing of the economy, for which it is necessary to formulate uniform unambiguous basic concepts that are "legalization (laundering) of illegally-obtained income", "counteraction to the economic shadowing", which determine the actual direction of the activities of these subjects and correlate the use of appropriate complex measures and facilities.

Key words: socio-economic security, state security, legal regulation, shadowing of economy, counteraction of corruption, legalization (laundering) of illegally-obtained income.

JEL Classification: F52, G1, H2

\section{Introduction}

The last decade was marked by the intensification of the search for means of ensuring the economic security of the highly developed countries of Europe, which requires the consolidation of the efforts of the scientific community in such basic directions as: unification of terminology, in particular, concerning the subject-matter and the content of counteraction to the legalization of illegally-obtained income, the financing of terrorism, the correlation of such concepts with other related concepts. Today, the legalization of the economy, capitals is perceived simultaneously as a positive activity, an active policy of the Government in order to maximally effectively manage the Ukrainian economy, which is an important component of accelerating the economic growth of its withdrawal from the "shadow" relations: in fact, the way of "unshadowing of the economy" through "legalization of the economy" is indicated. In the Basic Law of Ukraine "On Prevention and Counteraction of the Legalization (Laundering) of the Proceeds from Crime, Terrorist Financing and the Financing of the Proliferation of Weapons of Mass Destruction" (Law, 2014), "legalization" is used in the opposite sense and is defined as any action associated with the commission of a financial transaction or a transaction with assets obtained as a result of crime (Law, 2014). From this thesis, it is clear that in Ukraine, the legalization of only those assets is counteracted that are obtained through the commission of crimes (which must be confirmed in accordance with the procedure established by the Criminal Procedure Code of Ukraine), and in relation to other offenses, the issue is open.

\section{Definition of concepts "legalization of income" and "shadow economy" in national legislation}

It should be noted that the content and essence of the concept of "shadow economy", "shadowing" are debatable; some scholars-economists call them "purely economic", the concept of "legalization" - by the content and essence is just legal. An analysis of laws and regulations that define certain measures to counteract the legalization (laundering) of proceeds from crime allows us to conclude that they actually emphasize the fact that this phenomenon and the shadow economy, the shadowing of the economy are not identical, at the same time, the relation between these concepts and phenomena marked by them are not revealed.

In addition, it is noted in separate publications that the sign of the shadow economy is the illegality of the origin of the sums, including in its mathematical indicators. Consequently, according to the authors of such approaches, the way to reduce the shadowing of the economy is the legalization of "shadow capital".

The legalization of shadow capitals is a process of introducing shadow capitals into the legal sphere of economic activity for the purpose of their legitimate accumulation, that is, receiving "purified income" or "reproduced-additional fictitious income" (Popovych, 2001).

The above gives an opportunity to summarize the use of the same concept of "legalization of capitals" as both positive and negative for society. The occurrence of the situation, which leads to significant terminological confusion, is obvious. The need for eliminating such a double understanding is realized, and an example of specifying what this is about is the phrase in the title of the Law of Ukraine "On Prevention and Counteraction to Legalization (Laundering) of the Proceeds from Crime, Terrorist Financing and the Financing of Proliferation of Weapons of Mass Destruction". That is, illegal is the legalization activity in the sense of "money laundering". The stated approach to clarifying the content of the established legal concept through the introduction of another one is quite doubtful.

Moreover, in the specified legal act in Article 1, which is devoted to the definition of terms used in the Law, the term "legalization (laundering)" is not disclosed, and this can be regarded as the fact that there is its fixed definition that is inadvisable to be given; along with this, Article 4 of the Law states that legalization (laundering) of proceeds from crime includes any actions related to the commission of a financial transaction or a transaction with assets obtained as a result of the commission of a crime, as well as the commission of actions aimed at concealing or disguising the illegal origin of such assets or possession of them, rights to such assets, sources of their origin, location, movement, change of their form (transformation), as well as the self-acquiring, possession or use of assets obtained as a result of the commission of a crime (Law, 2014). That is, as in the case of the 
definition of the concept of "shadow economy", without the possibility to provide a common definition, the authors characterise a certain activity, calling its features, aimed at distinguishing such an activity from the activity of other types, in essence, from crimes of other types.

Another legal term to be distinguished from the "legalization" of capital is "legitimization", in particular, of entrepreneurial activity. It is understood as one of the measures of public regulation of economic activity in Ukraine aimed at confirming the legality of the entry of its subjects in economic circulation and may include state registration, licensing, patenting, quota arrangement. At the same time, if the first element of legitimization is mandatory for those who seek to become entrepreneurs, then the latter are optional and depend on the specific type of economic activity the entrepreneur wants to engage in. The relations of legitimization of economic activity are bilateral. On the one side is their initiator a business entity (natural or legal person), on the other an authorized body, which can be a public authority or local self-government bodies (public administration). At different stages of legitimization, the quality of the composition of such entities may vary. Thus, during state registration of entrepreneurs, on the one hand, the subject of legitimate relations is a state registrar, and on the other - the founder of a legal entity or an individual who wishes to become an entrepreneur. In the further relations of legitimization, the latter party acts already as a registered partnership or individual entrepreneur. Therefore, legitimization is a consistent implementation of certain actions, the execution of which is ensured by public administration bodies (Kovalenko, 2011). Legitimacy is a mandatory sign of the legitimate power of the state, which means recognition of it both within the country and in the international arena. Scholars caution that this concept should not be confused with the concept of legality as a legal characteristic. Since any authority, if it issues laws and enforces them, is legal. At the same time, it can remain unrecognized by people, that is, to be illegitimate. However, for example, not only legitimate but also illegal power - the power of "shadow merchants", mafia structures, can operate in a society (Shemshuchenko, 2007).

\section{The concept of "counteraction" in the domestic legal doctrine}

It is necessary to clarify and disclose the content of the concept of "counteraction", which is currently the most used to refer to activities directed against various types of offenses (in particular, corruption and related to corruption, legalization (laundering) of proceeds from crime, etc.), and therefore, the most acceptable to denote activity against the shadowing of the economy.

The term "counteraction" is of foreign origin, translated as "an act that serves as an obstacle to the emergence or development of another action, resistance", “opposition" or "active opposition" - from English counteraction; "resistance to someone, something" entgegenwirken (German). The given English variant has a consonant analogue in Ukrainian - "контракція", which means counteraction ("контр" - counter, "акція" - action). The German version is also almost literal: "entgegen” - "counter", “wirkung” - "action, influence” (Vyshnevetskyi, Trofymenko, 2013). The issue of defining the concept of counteraction and its essence in more detail was considered within the criminal law sciences in connection with the definition of activities directed against crime. So, V. V. Kovalenko, distinguishing the shadow sector of the economy, concludes that the latter exists as a structure, which purpose is to use for mercenary purposes the shortcomings of the state regulation of social relations in the field of the economy, public administration of the economy, etc., and includes a set of conscious measures to counteract the processes of qualitative development of the economic sphere of the country (Kovalenko, 2004). O. M. Bandurka and O. M. Lytvynov define counteraction to crime as a special integrated, multilevel object of social management, which is a diverse by forms activity of the relevant actors (state, non-state bodies and institutions, public formations, and individuals) that interact in the form of a system of heterogeneous measures aimed at the search for ways, means, and other possibilities of effective influence on crime in order to reduce the intensity of determination of crime at all levels, neutralization of its causes and conditions for the restriction of the number of criminal manifestations to a socially tolerant level (Bandurka, Lytvynov, 2011).

In general, supporting this definition, it should be pointed out that in this work and in many other criminological studies, first of all, the difficulty of establishing clear boundaries between the terms used to refer to the whole range of methods of influencing crime - counteraction and fight - is noted. In this regard, it is proposed to use them as synonymous (Bandurka, Lytvynov, 2011). On this issue, A. I. Dolhova points out that the most accurately the content of such an activity is reflected in the concept of "fight against crime" because it covers the impact on the causes of crime and the crime itself, shows the complex, voluminous nature of such influence; and emphasizes the active moment of an attack on crime during its counteraction (Criminology: Dolhova, 2012). With this argument, the scholar actually states that the fight is only one of the components of the counteraction, its active moment. This is an extension of the content of the term "counteraction", including the term "fight" to it, as other scholars suppose. However, such an approach to defining the purpose of counteraction - directing it to the fight is rather doubtful. The inexpediency of spreading this approach regarding the definition of the impact on such a threat as the shadowing of the economy is indicated in the previous author's publication (Tylchyk, 2017). 
Recognizing the need to take into account the achievements of the criminal law sciences on the problems of counteraction, it should be emphasized that today it is precisely in administrative-legal rules that the principles of ensuring counteraction to threats to national security, in particular, partly in the sphere of the economy, that is, the shadowing of the economy, are revealed. In addition, a large array of administrative and legal means and measures aimed at ensuring the legality of the economy, as well as the procedure and conditions for the activity of the subjects of providing who are the subjects of administrative law, is being developed. Therefore, it is expedient to study the issue of counteraction in the administrative-legal aspect.

Proceeding from the etymological essence of the term "counteraction", it is quite logical to define its content as an activity directed against a negative action - "antiaction and/or anti-activity", completing the phrase by an adjective which denotes a negative phenomenon (for example, anti-extremist activity). The above will emphasize the nature of the term "counteraction". However, the use of the aforementioned, namely theoretical, phrase (anti-activity) in relation to other negative manifestations, in addition to the antiterrorist activities perceived in scientific circles, should be taken with caution, as it may bring into the use (science) concepts that will replace the established scientific terminology and cause confusion during practical activity. The "counteraction" vector will be determined by the nature of the latent behaviour of the subjects, which directly or indirectly affects the vital legitimate interests and rights of individuals and will be characterized as a threat. This is evidenced by the doctrinal work of the considered issue, in particular, when forming elements of the state counteraction policy, which should include issues that reflect problems of the organization and implementation of counteraction, which is accompanied with identifying vital interests in various spheres of state and social life, revealing real and potential threats, forecasting probable changes in the assessment of interests and threats and, in this regard, the general state of security, and determining specific countermeasures adequate to the threats and sufficient to overcome them (Tylchyk, 2016).

Counteraction, implying the influence on social relations, does not level out the individuality of its implementation. Therefore, the allocation of the concept of "individual counteraction" or "narrowly directed" will substantially limit its subject and will not be scientifically and practically valuable. Taking into account the above, the characteristic of administrative-legal counteraction as an active activity, the purpose of which is to ensure the passive behaviour of the subject of administrative legal relations, prevent violations of administrative-legal rules, appears to be objective. That is, activities aimed at providing one of the forms of implementation of rules of administrative law - observance. It is entirely logical to conclude that the provision of such a form of implementation as observance has a coercive character, which is understood as the compulsion of a person to consciously carry out certain actions or to refrain from them, obey contrary to their will.

Recently, the discussion on the problem of the definition of counteraction to various social negative phenomena as objects of administrative-legal regulation revived. At the same time, the authors mainly indicate that such a counteraction is a complex of measures of influence carried out by the subjects of public administration, who are responsible for identifying the causes and conditions that contributed to certain violations of legal prescriptions, preventive measures, prevention of such violations, termination of such violations, elimination of their consequences, and bringing the perpetrators to responsibility, which is provided on the basis of the rules of administrative law, aimed at regulating social relations in order to ensure the constitutional rights and legitimate interests of man and citizen.

Pointing to the circle of subjects of counteracting the shadowing of the economy, it should be taken into account that in the sphere of the economy, both citizens and representatives of public administration perform activities, in particular, in the process of managing objects of state ownership form. Most clearly this can be demonstrated by the example of managing the production complex of the criminal-executive system. Therefore, we consider definitely incomplete the statement that counteraction is a complex of measures aimed at regulating social relations in order to ensure the constitutional rights and legitimate interests of man and citizen. It is quite important to supplement it with the need to provide public administration actors with effective means of influence, including administrative coercion, in order to exercise their powers strictly in accordance with legal instructions.

\section{Conclusions}

Defining the concept of counteraction to the shadowing of the economy, it is expedient to clarify that the activities of subjects are ensured on the basis of rules of not only administrative law but also other branches of law, for example, criminal - in relation to determining the grounds for bringing people to criminal liability for crimes in the economy (including money laundering, terrorism financing), etc.

Counteraction to the shadowing of the economy a complex of measures of influence of subjects with the appropriate legal status for identifying the causes and conditions that contribute to violation of the requirements established by the legal rules for activities in the field of economy, preventive measures, prevention, termination of such violations, elimination of their consequences, and bringing the perpetrators to responsibility in order to prevent the negative transformation of the economy 
(which will lead to a material result that is not reflected in GDP) and preventing the formation of threats to economic security. Such a counteraction can be effective in the case of its complex nature in relation to the said offenses, which may include certain corruption offenses, offenses related to corruption if they lead to the formation of corresponding material results (income - for a broad understanding of this concept).
Today, the key is that it is precisely within the framework of counteraction to the shadowing of the economy that the counteraction to the money laundering is provided. This very thesis should define the conceptual foundations and find a reflection in domestic legislation and in the legislation of other countries, which seek to form an effective system of economic security.

\section{References:}

The Fifth Round Mutual Evaluation Report on Ukraine regarding anti-money laundering and counter-terrorist financing measures (30 January 2018). The MONEYVAL Committee. Retrieved from: https://rm.coe.int/ fifth-round-mutual-evaluation-report-on-ukraine/1680782396

Tylchyk, O. (2017). Administrative and legal provision of counteraction to shadow economy: the monograph. Publishing House "Helvetica", Kyiv, 378 p.

On prevention and counteraction of legalization (laundering) of the proceeds from crime, terrorist financing, and the financing of proliferation of weapons of mass destruction: Law of Ukraine (2014) on 14 October 2014 № 1702-VII. Retrieved from: http://zakon.rada.gov.ua/laws/show/1702-18

Popovych, V. M. (2001). The theory and practice of the unshadowing of the economy: monograph. Irpin: National Academy of SBGS of Ukraine, 546 p.

International Police Encyclopaedia (2011). Ed. by: V. V. Kovalenko, Yu. I. Rymarenko, V. Ya. Tatsii, Yu. S. Shemshuchenko. K.: Atika, Vol. 7: Administrative-legal provision of police activities, 1120 p.

Great Encyclopaedic Dictionary of Law (2007). Ed. by Yu. S. Shemshuchenko. K.: Yurydychna Dumka, 421 p.

Vyshnevetskii, K. V., Trofimenko, S. V. (2013). On terms "fight" and "counteraction" in criminal legal vocabulary. Retrieved from: http://teoriaractica.ru/rus/files/arhiv_zhurnala/2013/3/yurisprudentsiya/vishnevetskiytrofimenko.pdf.

Tylchyk, V. V. (2016). Determination of the concept of "administrative and legal counteraction". Visegrad Journal on Human Rights, 5(1), 164.

Kovalenko, V. V. (2004). Organization of prevention of economic crimes in Ukraine: extended thesis abstract for Dr. Sc. (Jurisprudence). Kh., p. 32.

Bandurka, O. M., Lytvynov, O. M. (2011). Counteraction to crimes and crime prevention: monograph. Kh.: KhNUIA, p. 44.

Criminology: textbook (2012). Edited by A. I. Dolhova. 4th Edition, Revised and Expanded. M.: NORMA INFRA-M, $1008 \mathrm{p}$. 